This article was downloaded by: [University of Sydney]

On: 04 May 2015, At: 09: 10

Publisher: Routledge

Informa Ltd Registered in England and Wales Registered Number: 1072954

Registered office: Mortimer House, 37-41 Mortimer Street, London W1T

3J H, UK

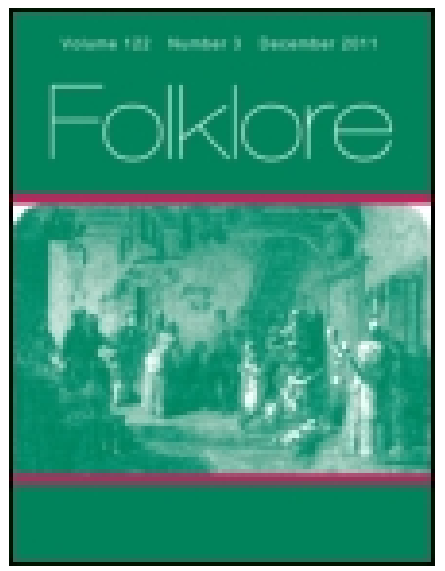

\title{
Folklore
}

Publication details, including instructions for authors and subscription information:

http:// www. tandfonline.com/loi/ rfol20

\section{The Story of Deirdre, in its Bearing on the Social Development of the Folk-Tale.}

Eleanor Hull

Published online: 06 Feb 2012.

To cite this article: Eleanor Hull (1904) The Story of Deirdre, in its Bearing on the Social Development of the Folk-Tale., Folklore, 15:1, 24-39, DOI: $10.1080 / 0015587 X .1904 .9719383$

To link to this article: http:// dx. doi.org/ 10.1080/0015587X.1904.9719383

\section{PLEASE SCROLL DOWN FOR ARTICLE}

Taylor \& Francis makes every effort to ensure the accuracy of all the information (the "Content") contained in the publications on our platform. However, Taylor \& Francis, our agents, and our licensors make no representations or warranties whatsoever as to the accuracy, completeness, or suitability for any purpose of the Content. Any opinions and views expressed in this publication are the opinions and views of the authors, and are not the views of or endorsed by Taylor \& Francis. The accuracy of the Content should not be relied upon and should be independently verified with primary sources of information. Taylor and Francis shall not be liable for any losses, actions, claims, proceedings, demands, costs, expenses, damages, and other liabilities whatsoever or howsoever caused arising directly or indirectly in connection with, in relation to or arising out of the use of the Content.

This article may be used for research, teaching, and private study purposes. Any substantial or systematic reproduction, redistribution, reselling, loan, sub-licensing, systematic supply, or distribution in any form to anyone is 
expressly forbidden. Terms $\&$ Conditions of access and use can be found at http://www.tandfonline.com/page/terms-and-conditions 


\section{THE STORY OF DEIRDRE, IN ITS BEARING ON THE SOCIAL DEVELOPMENT OF THE FOLK.TALE.}

BY ELEANOR HULL.

(Read at Meeting, 18th November, 1903).

$\Lambda$ FOLK-TALE may be studied from two quite different points of view. It may be regarded as a single example of a larger or smaller world-wide class of folk-stories having points of resemblance to each other, or it may be studied historically in its relation to the social development of the country in which it has had its origin. There is a danger in the pursuit of folklore studies that this historic sense should be subordinated to the mere accumulation of examples, and the era of the historical development of the folk-tale can only recently be said to have begun. Yet we have perhaps no surer reflection of the mental and moral changes of attitude in a nation than that which the evolution of a popular folktale gives us. Do the folk believe firmly in the supernatural? The story assumes grave and weird proportions. Do they grow sceptical? The folk-tale dwindles into the comic or grotesque. Are they fierce and cruel? The folklegend is gloomy and vindictive too. Does civilisation stamp out these qualities? The change is often well expressed in the modern aspect of the tale. When the folkstory is studied wholly from the standpoint of its external similarities and ramifications, this most instructive side of its history is apt to be lost sight of, and its value as a guide to the social and intellectual development of a people is impaired.

We propose, in this paper, to sketch the development of a well-known Irish tale through some of the changes which it has undergone during a steady course of popularity over six or seven hundred years. 
Perhaps the most familiar of all the stories of heroic Ireland is the Tale of Deirdre, or the "Tragical Death of the Sons of Usnach." When the legends of the heroic period of Irish literary production fell into disuse, when even the popular "Wooing of Emer," the "Täin B6 Cuailgne," and the "Feast of Bricriu" grew hazy in the people's tradition, the Sorrowful Tale of Usnach's Sons seemed endowed with perennial vitality. It is still at the present day the best known of all the large stock of Irish romances, and on it the art of living musicians, poets, and story-tellers has exercised itself with the result, at all events, of keeping its memory alive.

One consequence of its long-continued popularity we wish to point out in this paper. While many of the great cycle of tales to which this romance belongs have come down to us without essential change, save the introduction of Christian ideas here and there, this story has undergone a continuous series of alterations, not only in details but even in the character of the principal personages, especially those of the heroine and her nurse, Levarcham.

The Deirdre of the ancient tale, forceful of purpose, fiercely determined at all hazards to gain her ends, and, spite of the steadfastness and strength of her devotion, showing in her conduct the savagery of an untamed nature, becomes softened in a later surviving form of the tale preserved in a 17 th or 18 th century manuscript into the tearful, sentimental maiden of a century ago. It is curious to find the wild woman of the 12 th century Book of Leinster version transformed into the Lydia Languish of a later age.

Levarcham, too, has in this late version lost her repellent qualities; the terrible magician of the early tales has changed into a fond and foolish old nurse who cannot resist the wilful pleadings of her charge.

The change is very marked and curious, and it represents the vast revolution in social manners and modes of thought in Ireland between the time of the first creation of the story 
in the mind of some gifted artist centuries ago and the time of its latest redaction.

Between these two Deirdres, the forceful, uncontrolled and barbaric Deirdre of the IIth and I th centuries and the sobbing and fibbing Deirdre of the 17 th or 18 th centuries, we find Deirdres of many kinds, less fierce but not less resolute, more gentle but not less fearless.

The earliest existing version is that in the Book of Leinster; the latest with which we shall here deal is a manuscript copy recently discovered by Dr. Hyde in the Belfast Museum, and published by him in the Zeitschrift für Celtische Philologie. Only the earlier portion of the tale is dealt with in the modern version, and we shall therefore confine ourselves to the same limits.

The general outline of the story is so well known that we need not linger over it. It is in brief as follows.

Conor, King of Ulster, and his warriors, are feasting, according to the custom of the day, in the house of one of the king's courtiers, when, amid terrible signs and portents, there is born to the wife of the host a fair daughter. Cathbad, Druid and Soothsayer, rises from the feast and utters a prophecy about the child so full of dismal warning to Ulster that the warriors, with one voice, determine to slay her on the spot. But the king intervenes. "It is not well," he says, "to kill a helpless infant; moreover, Cathbad has foretold that the maiden will be fairer than all women of the world; the king will himself rear up the child, and will in due time take her as his one and only wife." So spake the old chief, and none of his warriors dared oppose him.

Deirdre (so named by the seer) was thenceforward shut up in a lonely fort, strictly guarded. Every luxury was provided for her, but, save for her foster-parents (or according to the later versions, Cathbad), and Levarcham the Druidess, and the king himself, none dared approach her. So Deirdre grew up, increasing day by day in loveliness, until, come to years of discretion, she suddenly began to feel 
conscious of the hardness of her fate, which bound her to a king indeed, but one old enough to be her father. Then it was that, seeing one day a raven drinking the blood of a newly-killed calf upon the snow, she confided to Levarcham her desire to have a husband as handsome as those three colours, black like the raven, red like blood, and white as snow. Levarcham tells her of Naisi, the brave and noblyborn son of Usnach. The story, in the oldest version, proceeds as follows:

"One day Naisi, alone upon the rampart of the fort, was singing. So melodious was his voice that all who heard it were soothed and ravished with the sound; the kine also and other animals, hearing it, gave milk two-thirds more than the usual supply. Valorous were the three sons of Usnach. If the entire province of Ulster had been attacked, they three, set back to back, would have secured victory to the Ultonians, so superior was the prowess of their defence, and the vigilance with which they would have protected each other. In the chase, they were fleet as hounds; they outstripped the wild beasts in their flight and killed them.

"When Naisi was alone without, Deirdre slipped out and passed him by. On the moment, failing to recognise her-

"'She is lovely,' he said, 'the heifer who passes by.' replied.

"'There must be fine heifers where the bulls are,' she

"'The foremost bull of the province is beside you,' he replied, alluding to the King of Ulster.

" If I were to make choice between you two, I would choose a bull, young like thyself', she said.

" 'Not so,' cried Naisi; for the prophecy of Cathbad came to his recollection.

"'Do you say that to get rid of me?'

"' Be it so,' he replied.

"At these words she flung herself on him, and seizing him by the two ears, she said, 'Behold thy two ears 


\section{The Story of Deirdre, in its bearing on the}

marked with scoffing and disgrace, if you do not take me with you.

"Away from me, O woman!"

"'I shall be thine,' she said.

"Then Naisi began to sing. At the sound of his melodious voice the Ultonians arose and turned their arms against each other.

"The sons of Usnach departed from their dwelling to find out what had become of their brother.

"'What are you about?' said they; 'is it not through your fault that the Ultonians are slaughtering each other?'

"Then Naisi told them all that had happened to him.

"' Nought but evil can come of it,' said the warriors; 'nevertheless, whatever may result, so long as we live we will not allow you to suffer an affront. We will take her with us to another province. There is not a king in Ireland who will not bid us welcome.'

"So they resolved. They departed before nightfall with Deirdre, three times fifty warriors, three times fifty women, and three times fifty dogs and attendants."

In one of the versions preserved for us by $O^{\prime}$ Flanagan in the pages of the short-lived Transactions of the Gaelic Society, 1808 , the fierce allusions and barbaric action of Deirdre are somewhat modified. It is interesting to see the transition to gentler manners, to catch it half-way, as it were.

The passage runs as follows:

"As Naisi was alone abroad, Deirdre threw herself in his way, but as she passed by, uttered not a word.

"'Gentle is the dame who passeth by,' says he.

"'It is natural for damsels to be gentle where there are no youths,' she said.

"'The man of the province [i.e. the king] is with you,' said he.

"If I were to make a choice between you twain, I should prefer a young man like you,' she answered. 
" ' Not so,' he said, 'for dread [of the king] is upon me.'

"'It is to escape me thou sayest that,' she said.

"'Be it so then,' he replied.

"On that she flung a ball at him, striking him on the head.

'A stroke of disgrace through all your life will this be,' she cried, 'if you take me not.' And with that she took up his instrument and played."

In the modern version, this wild scene is entirely omitted. We are simply told that Levarcham, overcome by Deirdre's childish woes, fetches Naisi to talk with her; and that he, filled with love at sight of her beauty, is easily persuaded to carry her off to Alba.

On the contrary, the incident of the raven drinking the blood spilled upon the snow, which inspired in the girl the desire to have a husband who should have hair black as the raven, cheeks red as blood, and a skin white as snow, becomes the centre of a series of scenes between Deirdre and her old nurse, which, charming and dainty as they are, are wholly modern in spirit. The claracter of both women has been transformed. We cannot fail to be struck by the similarity between these scenes and the famous conversation between the love-lorn Juliet and her nurse in Shakespeare's play. Save that Levarcham is here more gentle and affectionate than Juliet's nurse, the pretty play between the two old women and their young charges is wonderfully alike.

To take a passage. "It chanced upon a day, while the snow was lying on the ground in winter, that Cailcin (i,e Cathbad), Deirdre's tutor, went to kill a calf to prepare food for her, and the blood being shed upon the snow, a raven stooped down to sip it. As Deirdre observed that, watching through a window in the fortress, she heaved so heavy a sigh that Cailcin heard her. 'Why art thou so sad, girl?' he said. 'Alas! that I have not yonder thing just as I see it,' said she. 'Thou shalt have it if it be possible,' he replied, and drawing his hand dex- 
terously, he gave an unerring cast of his knife at the raven, so that he cut one foot off it, and taking up the bird, he threw it over beside Deirdre. The girl gave a sudden start, and fell into a faint, till Levarcham came to her aid. 'Why art thou thus, dear daughter?' said she; ' thy countenance is piteous ever since yesterday.' 'A desire that I chanced to have,' said Deirdre. 'What is that desire ?' said Levarcham. 'Three colours that I saw,' said Deirdre, 'the blackness of the raven, the redness of the blood, and the whiteness of the snow.' 'It is easy to satisfy thee so far,' said Levarcham; and she arose and went out immediately ; and she gathered the full of a vessel of snow, and half the full of a cup of the calf's blood, and three feathers pulled out of the raven's wing, and she laid them down on the table in front of the girl. Deirdre made as though she were eating the snow, and lazily tasting the blood with the tip of the raven's feather, her nurse closely watching her the while, until Deirdre begged Levarcham to leave her alone for a time.

"So Levarcham departed, but returning again she found Deirdre shaping a ball of snow into the likeness of a man's head, and mottling it with the tip of the raven's feather out of the blood of the calf, and arranging the small black plumage upon it like hair. Until all was finished she never noticed that her nurse was scanning her.

"'Whose likeness is that?' said Levarcham. Deirdre started, and she said, 'I can easily destroy my work.' 'That work of thine is a great surprise to me, girl,' said the nurse, "because it is not like thee to draw pictures of a man, and, moreover, the women of Emania were not permitted to teach thee the similitude of any man but of Conor only.' 'I saw a face in my dream,' said Deirdre, 'that was brighter of countenance than the face of the king or of Cailcin, and it was in it that I saw the three colours that troubled me, for his skin was white like snow, and the blackness of the raven was on his hair, and in his face the red tint of blood; 
and woe is me, for unless my desire is given to me, I shall not live.' 'Alas for thy desire, it is difficult to obtain it,' said Levarcham, 'for fast and close is the fort of the (Red) Branch, and high and difficult the enclosure round about, and within are the fierce bloodhounds keeping watch.' 'The hounds will not harm us,' said Deirdre. 'Where did you behold that face?' said Levarcham again. 'In a dream yesterday,' said Deirdre weeping; and she hid her face in the bosom of her nurse, shedding tears plentifully. Her nurse lifted up Deirdre's head. 'Take courage, daughter,' she said, 'and be patient, and surely thou wilt get thy desire; for according to the span of human life, Conor's time beside thee cannot be long.' Levarcham then departs, but as she is crossing a passage she notices a green mantle hung loosely across a closed-up window, and putting her hand to it it came readily away, the moss and stones falling down after it; and beyond, through the gap, might be seen the Plain of the Champions, and the heroes exercising themselves on it in games and feats of strength. A new light breaks in on Levarcham's mind. 'I understand now, my pupil,' she thinks, ' where you saw that dream.'"

Some little time after she goes back to look for Deirdre, and finds her lying on her couch, crying and making moan. The heart of the old nurse is softened at the sight, and bending over her, she bids her tell her whether she had ever before seen the warrior whom she had been shown yesterday in the dream, or whom she had perhaps seen through the hole bored in the window-work? Then Deirdre hiding her face against her nurse's shoulder, tells her under promise of secrecy a pretty childish romance. She said that once when she was but a little girl, she had seen him on the lawn of the royal residence, playing games with the other boys, and learning feats of championship, and that even then he had already been beautiful to look upon.

" Daughter," said Levarcham, "it is full seven years since you saw the boys playing on the green, and then you were 


\section{The Story of Deirdre, in its bearing on the}

but seven years of age." "Seven bitter years," said Deirdre, " since I beheld the joyous sports on the green, and the games of the boys; yet even at that time Naisi surpassed all the youths of Emania." "Naisi, the son of Usnach?" said Levarcham. "Naisi was his name, he told me so," said Deirdre, "But I did not ask whose son he was." "He told you so!" exclaimed Levarcham. "He told me so," said Deirdre, "when he threw the ball, by a mis-cast, backwards, across the heads of the group of maidens who were standing on the edge of the Green, and I rose from among them all, and picked up the ball, and gave it back to him, and he pressed my hand joyously." "He pressed your hand, girl!" cried Levarcham. "He pressed it lovingly, and said that he would see me again, but it has been difficult for him, and not until yesterday have I seen him since; and $O$ gentle nurse, if you would not wish me to die, take a message to him from me, and bid him come and talk with me to-night, without the knowledge of Cailcin or any other person."

Again Levarcham objects that the difficulties are insurmountable, and in especial that Naisi is much beloved of the king, who is his near relation. Deirdre will admit no impediment, and she ends by bidding her nurse remember that Naisi has great territories in Alba (Scotland), and that she would have her tell him how much greater is her love for him than for the king. "Tell him that yourself, if you can," cries Levarcham, as she ultimately goes away to do Deirdre's bidding.

Finally Naisi carries her off, not to a painful circuit through various parts of Ireland, as in the earlier version, but directly to his own possessions in Alba.

Now, pretty as this modern version is, it has quite parted with the heroic elements of the earlier romance.

This fanciful, sensitive girl, who trims snowballs into the shape of her lover's head, who dissolves into tears and betakes herself to the sofa, who falls into a faint at sight of the three colours that have possessed her imagination, is as 
unlike as it is possible to conceive to the original Deirdrethe girl who throws herself across Naisi's path, ferociously seizes him by the ears, or, according to the slightly later version, flings a ball at him as he passes by. The changed ideas of a woman's proper position and course of action could not be more strikingly illustrated. She no longer takes measures to secure the fulfilment of her wishes; she weeps in secret and builds imaginary lovers out of snowballs. Had it not been for Levarcham, who undertakes the perilous position of intermediary for a girl who is no longer courageous enough to take her own fate into her hands, she would never have met Naisi again; she would probably have cried on the sofa to the end of her days. We will not discuss which was the more admirable Deirdre, but I confess to finding it difficult to realise that the Deirdre who cried and fainted would have become the heroic champion of her husband's cause, the calm and composed woman who, with imperturbable courage, played chess with her husband when the house was surrounded by their direst foes, and an enemy was watching them through the window; or to imagine in her the woman who, when Naisi was dead, dashed her brains out upon a rock that she might escape the cruelty of Conor and Eogan.

You will notice that the character of Levarcham is also changed. Here, in the modern story, she is only the affectionate, fond old nurse, who, woman-like, is inquisitive about the freaks of her ward. She is fearful of the king's anger, yet pleasantly interested in the romance of the two young people; and she is brought without much difficulty to consent to their meeting.

She is a much more redoubtable personage in the other stories. She is represented as Conor's messenger and "conversation-woman," meaning the royal woman of lamentation or professional "keener." She is possessed of extraordinary powers, for she can walk through the whole of Ireland in one day, acting apparently the part of a spy, and

vor $\mathbf{x y}$. 
picking up information useful for the royal ears. We read that " everything good or evil that was done in Ireland she used to relate to the king in the House of the Red Branch at the end of the day." When Conor was shut up during the famous Siege of Howth on the rocky heights of the peninsula, and unable to obtain a supply of provisions, he was sustained by a daily supply of food brought by Levarcham on her back all the way from the royal palace of Emain Macha (i.e. Navan Fort, near Armagh). When undergoing these prodigious feats a fearful and horrible change came over the swift messenger. We read that "her feet and knees turned and went behind her, and her heels and thighs came before her!" while, besides her ordinary share of food with the warriors, she required a portion of 60 cakes which she baked at one time on the fire. ${ }^{1}$ Though only the child of a slave-girl and born in Conor's house, Levarcham was possessed of all the arts of druidism. She was that most dreaded being, a female satirist. Even the king stood in awe of her, for we read that he would like to have removed her from the vicinity of Deirdre, but he dare not, for he dreaded her incantations.

So radically dissimilar are the maiden Deirdre and her nurse Levarcham in the story of the IIth and that of the

\footnotetext{
The same extraordinary description is given of Cáchulainn in moments of supreme action, and probably is meant, by some strange flight of the savage imagination which cannot be followed by the modern mind, to denote great strength or swifuess of body. The same is said of Dumbnall, a terrible Amazon in Alba, whom Cúchulainn met when be went thither to learn championship; and also of the Devil, who when bidden by St. Moling to fast and pray, replies, that he cannot kneel, because his knees ure behind him, see Stokes' Goidelica, 2nd edition 1872, p. 180. In a series of articles on Les Pieds at Genoux d rebours, published in Mélusine, vi. 172 ; vii. 39,$63 ;$ viii. 77 , M. IJenri Gaidoz shows that the idea, which is met with in various countries, generally represents an evil genius or redoubtable person. There is a tiny brunze statuette in the British Museun representing the grotesque figure of a youth or man with the lower portion of the body from the waist to the ankles turned in an opposite direction to the hend and feet. M. Perdrozet mentions a similar statuette in the National Museum at Athens.
} 
17 th century. The comparison is interesting not only as showing the variations through which a few of the more popular of the tales of old Ireland have passed, but yet more because these changes give us glimpses into the social and moral conceptions of the people themselves.

What the age demands, that the story-teller, if he desires to retain his popularity, must add to his recital; that which changed ideas of life and character reject, that he must needs remodel. Thus the tales become a touchstone by which the moral sensitiveness of the nation can, to a certain extent, be gauged. In the beautiful modern folk-version taken down by Mr. Alexander Carmichael from Iain MacNeill ("Iain Donn"), an old man of eightythree, in the Western Islands of Scotland,' the whole cast of the story is remodelled. Here it is not the king who shuts up the maiden to preserve her for himself, but her own father, who, on account of his great age and the age of his wife when Deirdre is born, is ashamed to be known to have a child. He therefore will not allow a living creature to know of her birth save the nurse or "knee-woman," alone. He gets three men to "dig a green conical mound inside out, and line the hollow thus formed right round," so that the child and nurse might live there comfortably. It is made far away from human habitation "among the great high hills in the wild distant desert," and it is provided year by year with food sufficient to last for twelve months and a day. The descriptions in this piece are of the loveliest, and we see Deirdre growing up in her solitude "lithe and fair as a stately sapling, straight and symmetrical as the young rush of the moorland. Her nurse-mother taught her all knowledge that she herself knew. There was no plant springing from root, nor bird singing from spray, nor star gazing from heaven, for which Deirdre had not a name." She is no longer the sentimental hothouse-reared

'Transactions of the Caelic Society, Inverness, vol. xiii, p]. 241.257. Translation, vol, xiv., pp. 370-387. 


\section{The Story of Deirdre, in its bearing on the}

girl of the modern Irish version, she is the sweet wholesome maid of the open hill and valley, moulded by the influence of storm and sunshine into their own fresh and changeful likeness.

"And beauty born of murmuring sound

Shall pass into her face."

Deirdre had grown to womanhood, and as yet she had never seen a man. But one wintry gloomy night a hunter who had lost his way sank down, exhausted with cold and hunger and overcome with drowsiness, outside the green mound in which Deirdre dwelt. "Sleep-wandering" came upon him, and he thought that he was at the abode of fairies, and that within he heard the fairies making music. In his dreams the hunter called out that if there were anyone in the house they should for the sake of the Good Being let him in.

"Deirdre heard the voice, and she said to the nursemother, 'Foster-mother, what is that ?' ' $\Lambda$ thing of little worth,' she replied; 'it is the birds of the air gone astray from each other, and seeking to come together again. Let them hie away to the forest of trees.'

"Again 'sleep-wandering' came upon the man, and he called out in his sleep that if there were anyone within the knoll, for the sake of the Being of the Elements they should let him in. 'What is that, nurse-mother?' said Deirdre. 'A thing of little worth,' she said again; 'it is but the birds of the flocks astray from each other, seeking one another and their home; but let them hie away to the forest of trees. There is neither house nor home for them here this night." Three times the benumbed and famished man called aloud, and three times the foster-mother gave her charge the same reply.

"'Oh! nurse-mother,' said the girl at length, 'the bird is asking shelter in the name of the God of the Elements, and thou thyself didst teach me that whatever is asked in 
His name should be done. If thou wilt not let me call in the bird that is benumbed with cold and sore with hunger, I myself will doubt thy teaching and thy faith. But, as I believe in thy teaching and the faith thou teachest me, I will arise and let in the bird." "'

Then Deirdre opened the door and set food and drink before the hunter.

While he is in shelter, the hunter lets his tongue wag, and he tells Deirdre of the three sons of Usnach and their strength and beauty, describing them under the same figures of speech as in the other tales. He is speedily dismissed with sharp words by the foster-mother, but having been much struck by the beauty of Deirdre, he thinks to make profit out of his discovery by relating the story to King Conor of Ulster, who is a widower. Inspired by his tales, the King and his party set out, and they perform with much fatigue and pain the journey to the lonely sheiling. They draw up before the door and knock, but nothing will induce the nurse to open the door, even when they threaten to break the bothie down and enter by force. "I would be obliged to you," said the woman, "to tell me who commands me to open my bothie door?" "It is I, Conor, King of Ulster," is the reply, "and let not the matter be in darkness to thee any longer." Then she is forced to obey, and the King carries off Deirdre and wishes to marry her at once, "for he had never in waking day or dreaming night seen a 'blood-drop' so lovely as Deirdre." But she would by no means consent, for "she had no knowledge of the duties of a wife or manners of a maiden, seeing that she never had seen the features of a man till now, nor sat in assembly or company before. Nor could she even sit in a chair, for she had never seen a chair till now." So she was allowed the respite of a year, and meanwhile she learned rapidly all that it was needful for her to know. One day as Deirdre and her maidens were sitting on the hill behind the house enjoying the scene and drinking the sunshine, 
Naisi and his brothers passed by. Though they did not look up, "the love of Naisi was so implanted in the heart of Deirdre" that she sprang up, gathered up her garments, and flew after them, leaving her companions astonished and displeased. Arden and Allen saw her following, and, knowing that she was affianced to the King, they hurried on, for they knew that if Naisi their brother saw her, he would have her for himself "seven times specially as she was not yet married to the King." So they exhorted one another to walk well, seeing that the distance was long that they had to travel and the darkness of night was coming on. Deirdre calls after him, "Naisi, son of Usnach, art thou going to leave me?" "What cry is that in mine ears that I cannot easily answer nor yet easily refuse?" said Naisi. "It is only the cry of the lake-ducks of Conor," they reply; "and let us hurry our footsteps, for the distance is great and the dark shadows of night are coming on." Thrice Deirdre utters her cry and thrice they assure their brother that it is only the grey geese or the flutelike notes of Conor's lake-swans that he hears. But at the third plaintive call, Naisi turns back and meets Deirdre, and she greets him with three kisses and one kiss to each of his brothers. "And glowing blushes like fire were in her cheeks for shame, and the tremulous hues of her ruddy cheeks were coming and going as fast as the shaking leaves of the aspen tree of the stream, till Naisi bethought him that he never saw in bodily form so lovely a 'blood-drop' as this, and he gave her a love such as he never gave to vision or living form, but to herself alone." Then he raised her on his shoulder and requested his brothers to walk well now, and that he would walk well with them. The flight to Alba and the end of the story is much as in the medizeval Irisl version, except that the three brothers are drowned in the magic sea raised by the Druid, and that when they are lying in the grave side by side Deirdre calls 
to them to make a place for her beside them. They do so, and she leaps into the grave, and lying down close to Naisi, she dies at his side.

This Highland version contrasts well with that preserved in the Belfast manuscript. The one has all the character of a drawing-room recital, full of sentimentality and artificiality; the other has the freedom and freshness of the place of its preservation among the wild tribes and ocean solitudes of the Outer Hebrides.

ELEANor Hull. 